\title{
Pengaruh Iklan, Kualitas Pelayanan Dan Kepuasan Konsumen Terhadap Loyalitas Konsumen Dalam Menggunakan Layanan Internet Indihome
}

\author{
Ermi Yandi ${ }^{1}$ \\ Ambar Lukitaningsih ${ }^{2}$ \\ Lusia Tria Hatmanti Hutami ${ }^{3}$ \\ ${ }^{1}$ Fakultas Ekonomi, Universitas Sarjanawiyata Tamansiswa \\ Email : davasa57@gmail.com \\ ${ }^{2}$ Fakultas Ekonomi, Universitas Sarjanawiyata Tamansiswa \\ Email : ambar.ita@ustjogja.ac.id \\ ${ }^{3}$ Fakultas Ekonomi, Universitas Sarjanawiyata Tamansiswa \\ Email : trialusia@ustjogja.ac.id
}

\begin{abstract}
Abstrak
Berkembangnya teknologi jaringan internet Indonesia Digital Home (Indihome) yang merupakan salah satu layanan yang berupa paket layanan komunikasi dan data, seperti telepon rumah, internet, dan layanan Televisi interaktif. Visi dari Telkom yaitu berupaya untuk menempatkan diri sebagai perusahaan Infocom terkemuka dikawasan Asia kawasan Asia Pasifik. Misi yang dimiliki PT. Telkom Indonesia yaitu memberikan pelayanan dengan jaminan bahwa pelanggan akan mendapatkan layanan terbaik, berupa kemudahan, produk dan jaringan berkualitas. Tujuan penelitian ini adalah untuk mengetahui bagaimana "Pengaruh Iklan, Kualitas Pelayanan Dan Kepuasan Konsumen Terhadap Loyalitas Konsumen Dalam Menggunakan Layanan Internet Indihome”. teknik yang dipakai dengan menggunakan metode purposive sampling. Ukuran sampel sebanyak 100 responden dengan menyebarkan kusioner yang diukur menggunakan skala likert. Hasil penelitian menunjukan bahwa iklan dan kualitas pelayanan tidak berpengaruh positif signifikan terhadap loyalitas konsumen, namun faktor kepuasan konsumen berpengaruh positif signifikan terhadap loyalitas konsumen dalam menggunakan layanan internet Indihome. Hasil dari penelitian ini diharapkan dapat memberikan informasi mengenai mengenai perilaku dalam menggunakan Layanan Internet Indihome dan faktor yang mempengaruhinya. Hasil dari penelitian ini diharapkan sebagai sumbangan pemikiran dan bahan pertimbangan perusahaan untuk meningkatkan penjualan produknya melalui perwujudan variabelvariabel penelitian yang mempengaruhi konsumen dalam menentukan pilihan pembelian dan juga dapat dijadikan sebagai acuan atau referensi dalam mengambil keputusan.
\end{abstract}

Kata kunci: Iklan, Kualitas Pelayanan, Kepuasan konsumen, Loyalitas Konsumen

\section{PENDAHULUAN}

Seiring dengan kemajuan zaman kebutuhan manusia semakin meningkat terutama di bidang teknologi. Perkembangan dunia teknologi saat ini memudahkan masyarakat untuk dapat memperoleh informasi. Indihome resmi diluncurkan pada tahun 2015. Salah satu sektor industri jasa yang sedang berkembang adalah penyedia jasa internet. Di Indonesia khususnya di kota besar pengguna internet semakin bertambah, baik itu pengguna internet pribadi ataupun yang warung internet umum (warnet). Faktor yang menyebabkan pengguna internet begitu banyak adalah banyaknya perusahaan penyedia jasa internet (Internet Service Providers / ISP).

Internet pada awalnya merupakan media browsing untuk keperluan militer dengan nama sebelumnya Arpanet (Advanced Research Project Agency Network) yang dibentuk oleh 'Departemen Pertahanan' Amerika Serikat pada tahun 1969 dalam Armanto (2018). Penilaian pelanggan Setelah menggunakan produk indihome, pelanggan yang puas tentunya akan memberikan ulasan positif sekaligus merekomendasikannya kepada orang lain. Keluhan dari masyarakat meliputi, adanya laporan pelanggan mengalami gangguan Fiber Optik (gangguan channel tv kabel, internet, dan telpon rumah), kualitas tv kabel yang buruk atau chanel tidak perbarui, laporan pelanggan telfon yang tiba-tiba sering terputus, laporan pelanggan internet yang melambat seiring pemakaian, laporan pelanggan Koneksi internet yang terputus secara tiba-tiba terkadang jaringan tidak memadai. Jaminan menumbuhkan kepercayaan pelanggan Indihome bertransaksi yang aman akan memudahkan pelanggan mendapatkan fasilitas internet yang memadai dan pelanggan internet Indihome di harapkan tidak terlambat dalam membayar tagihan internet Indihome, karena jika terlambat membayar maka akan di kenakan sanksi berupa denda atau jaringan anda bisa di blokir (terisolir) secara otomatis oleh pihak PT. Telkom 
Indonesia. Untuk menarik minat konsumen harus memikirkan konsep iklan sehingga konsumen mengetahui apa yang bisa didapat di dalam perusahaan, dengan memperkenalkan produk, mengingatkan, mengajak dan menjaga hubungan dengan konsumen akan tertarik pada produk yang ditawarkan.

Iklan menurut Noor (2018) adalah segala bentuk presentasi non-pribadi dan promosi gagasan, barang, atau jasa oleh sponsor yang tertentu yang harus dibayar. Pesan yang disampaikan kepada masyarakat melalui bantuan media, menyinggung media promosi benda seperti barang, dan ide yang disampaikan melalui media dengan sponsor.

Dengan kualitas pelayanan yang baik maka akan mempertahankan pelanggan yang lama maupun pelanggan yang baru untuk memenuhi kebutuhan. Persaingan yang semakin kompetitif menuntut perusahaan untuk menciptakan pemikiran-pemikiran baru dari kualitas pelayanan yang diberikan kepada konsumen untuk mempertahankan konsumen agar tidak beralih ke perusahaan pesaing. Menurut Wahyono (2018) bahwa kualitas jasa atau pelayanan adalah tingkat keunggulan yang diharapkan dan pengendalian untuk mencapai tingkat keunggulan demi terciptanya kepuasan pelanggan. Berdasarkan definisi diatas, kualitas pelayanan bisa diwujudkan dengan pemenuhan kebutuhan dan keinginan yang pelanggan harapkan dengan cara penyampaian yang tepat.

Kepuasan konsumen akan datang dengan sendirinya bila jasa yang ditawarkan oleh perusahaan sesuai atau bahkan melampaui yang konsumen inginkan. Konsumen yang puas akan membeli lagi dan mereka pasti member tahu orang lain mengenai pengalaman baik dari produk tersebut. Begitupun dengan kekecewaan konsumen jika perusahaan melakukan kesalahan sekecil apapun akan menimbulkan akibat buruk bagi perusahaan, jika konsumen tidak merasa puas maka meraka akan meninggalkan perusahaan dan akan beralih ke perusahaan lain.

Menurut Aulawi et al. (2016) berpendapat bahwa kepuasan merupakan evaluasi pelanggan terhadap sebuah produk atau layanan dalam kaitannya dengan apakah produk atau layanan tersebut dapat memenuhi kebutuhan dan ekspektasi mereka. Kegagalan untuk memenuhi kebutuhan dan ekspektasi dianggap sebagai ketidakpuasan terhadap produk atau layanan tersebut. mereka juga mengatakan bahwa kepuasan konsumen merupakan indikator penting bagi kesehatan ekonomi nasional dan kualitas hidup.

Dalam suatu bisnis berbagai pengalaman lebih membutuhkan konsumen yang setia akan membeli suatu produk. Pelanggan yang setia menurut Arnold, dan Reynolds, (2000) dalam Aulawi et al (2016) adalah: "Loyal customers build businesses by buying more, paying premium prices, and providing new referrals through positives world of mouth". True Loyalty Customer adalah konsumen yang bersedia melakukan pengorbanan untuk mencari jasa, lokasi atau merek tertentu. Spuriosly Loyal Customer yaitu konsumen cenderung dimotivasi oleh dorongan, keadaan, dan perilaku dengan catatan apabila kondisinya tepat. Latent Loyalty, konsumen dalam hal ini loyal karena tidak ada pilihan lain. No Loyalty, mereka adalah konsumen yang bersikap tidak loyal pada suatu merek perusahaan.

Menurut Noor (2018) langkah menuju loyalitas konsumen diawali dengan siklus pembelian yang terdiri dari tahapan kesadaran akan produk, pembelian pertama, lalu bertransformasi menjadi evaluasi pasca pembelian dan diakhiri dengan tahapan pembelian ulang. Posisi iklan dalam siklus pembelian adalah sebagai instrumen yang berfungsi menyadarkan konsumen tentang produk yang akan bermuara pada terbentuknya loyalitas konsumen.

Dengan alasan tersebut dan juga berdasarakan latar belakang di atas, maka penulis tertarik untuk melakukan penelitian dengan judul: "Pengaruh Iklan, Kualitas Pelayanan Dan Kepuasan Konsumen Terhadap Loyalitas Konsumen Dalam Menggunakan Layanan Internet Indihome". Pembahasan diatas dapat disimpulkan bahwa Iklan, Kualitas pelayanan, dan Kepuasan konsumen terhadap loyalitas konsumen menjadi salah satu faktor penting dalam menggunakan layanan internet indihome.

\section{Perumusan Masalah}

1. Apakah iklan berpengaruh terhadap loyalitas konsumen dalam menggunakan layanan internet Indihome?

2. Apakah kualitas pelayanan berpengaruh terhadap loyalitas konsumen dalam menggunakan layanan internet Indihome?

3. Apakah kepuasan konsumenberpengaruh terhadap loyalitas konsumen dalam menggunakan layanan internet Indihome? 


\section{KAJIAN PUSTAKA DAN PENGEMBANGAN HIPOTESIS}

\section{Loyalitas Konsumen}

Menurut Noor (2018) mendefinisikan loyalitas konsumen merupakan perwujudan dari tekat konsumen guna melakukan pembelian kembali terhadap suatu produk tanpa terpengaruh terhadap lingkungan. Sedangkan menurut Griffin (2005) dalam Asta \& Jaya (2019) konsep loyalitas pelanggan lebih banyak dikaitkan dengan perilaku daripada sikap, pembelian oleh seorang pelanggan bisa dikaitkan perilaku dan sikap adalah suatu perasaan yang diperlihatkan oleh seorang pelanggan setelah memakai produk atau jasa.

\section{Iklan}

Menurut Noor (2018) adalah segala bentuk presentasi non-pribadi dan promosi gagasan, barang, atau jasa oleh sponsor yang tertentu yang harus dibayar. Sedangkan menurut (Kotler, 2008) dalam Winarti (2016) Periklanan (advertising) adalah semua bentuk terbayar atas presentasi nonpribadi dan promosi ide, barang, atau jasa oleh sponsor yang jelas. Iklan bisa menjadi cara yang efektif dari segi biaya untuk mendistribusikan pesan, baik dengan tujuan membangun preferensi merek atau mendidik orang.

\section{Kualitas Pelayanan}

Menurut Armanto (2018) menyatakan bahwa kualitas pelayanan sebagai sikap konsumen yang berkaitan dengan hasil dari perbandingan antara harapan dari layanan dengan persepsinya terhadap kinerja aktual.

\section{Kepuasan Konsumen}

Menurut Noor (2018) kepuasan konsumen adalah perasaan senang atau kecewa seseorang yang muncul setelah membandingkan kinerja (hasil) produk yang dipikirkan terhadap kinerja yang diharapkan. Salah satu tujuan penting program kepuasan pelanggan adalah untuk meningkatkan loyalitas konsumen. Umumnya, kepuasan pelanggan yang tinggi dapat mengindikasikan adanya peningkatan loyalitas bagi konsumen yang sudah ada.

\section{Pengembangan Hipotesis}

Pengaruh iklan terhadap loyalitas konsumen dalam menggunakan layanan internet Indihome.

Menurut A. Putra (2017) istilah periklanan merujuk kepada pemahaman keseluruhan proses yang meliputi persiapan, perencanaan, pelaksanaan, dan pengawasan penyampaian pesan. Penelitian yang dilakukan Putri dan Rahayu (2011) dalam Paramananda \& Satria (2015) menyimpulkan bahwa iklan memiliki hubungan positif terhadap loyalitas konsumen. Menurut Dewi, Andri, Yonaldi (2012) dalam Winarti (2016) menyatakan bahwa iklan memiliki pengaruh yang signifikan terhadap loyalitas konsumen.

H1 : Iklan berpengaruh positif terhadap loyalitas konsumen Indihome

\section{Pengaruh kualitas pelayanan terhadap loyalitas konsumen dalam menggunakan layanan internet Indihome. \\ Menurut Wahyono (2018) mengemukakan bahwa kualitas pelayanan adalah tingkat keunggulan yang diharapkan dan pengendalian untuk mencapai tingkat keunggulan demi terciptanya kepuasan pelanggan. Penelitian yang dilakukan oleh Suwarni dan Mayasari (2011) dalam ( Jihan Nafisa,2018) yang menyatakan bahwa terdapat pengaruh yang signifikan antara kualitas pelayanan terhadap loyalitas pelanggan. \\ H2 : Kualitas pelayanan berpengaruh positif terhadap loyalitas konsumen Indihome}

\section{Pengaruh kepuasan konsumen terhadap loyalitas konsumen dalam menggunakan layanan internet Indihome.}

Penelitian yang dilakukan Sukawati (2018) kepuasan konsumen berpengaruh positif dan signifikan terhadap loyalitas konsumen. Hal ini mengidenifikasikan bahwa kepuasan konsumen menentukan loyalitas konsumen. Penelitian yang dilakukan Sawitri et al. (2013) dalam Kusuma (2019) memperoleh temuan bahwa kepusan pelanggan berpengaruh positif dan signifikan terhadap loyalitas pelanggan.

H3 : Loyalitas konsumen berpengaruh positif dan signifikan terhadap loyalitas konsumen internet Indihome. 


\section{Gambar 1. Kerangka Pikir Penelitian}
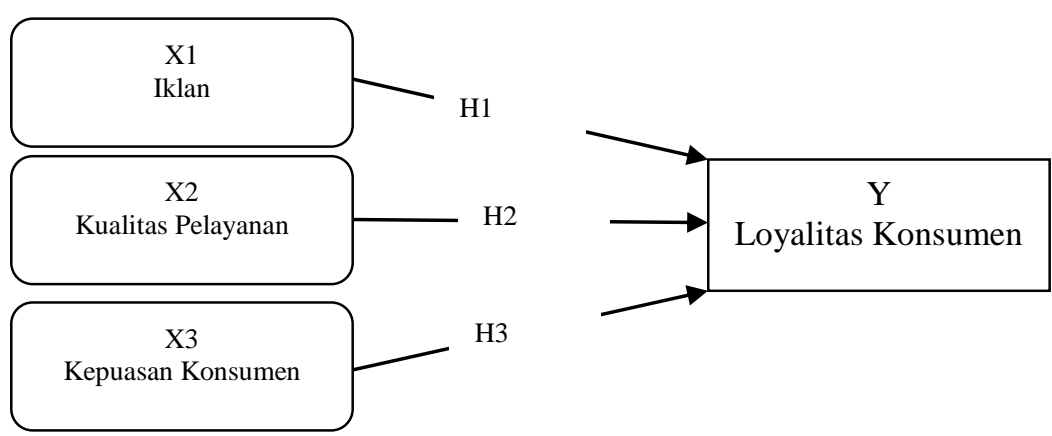

\section{METODE PENELITIAN}

Jenis penelitian ini adalah jenis penelitian deskriptif kuantitatif yang menggambarkan atau lukisan secara sistematis, faktual dan aktual mengenai fakta, sifat-sifat serta hubungan antar fenomena yang di selidiki. Menurut Sugiyono (2009) dalam Aulawi et al. (2016). Penelitian kuantitaif adalah suatu metode penelitian yang berdasar pada filsafat positivisme yang digunakan untuk meneliti populasi atau sample. Penelitian ini menggunakan metode penelitian kuantitatif dengan membahas dan menguji pengaruh iklan, kualitas pelayanan dan kepuasan konsumen terhadap loyalitas konsumen dalam menggunakan layanan internet Indihome. Penelitian ini dilakukan di Kota Yogyakarta, dengan mengambil subjek penelitian kepada para pengguna layanan internet Indihome.

\section{Populasi, Sampel dan Teknik Pengambilan Sampel}

Dalam penelitian ini yang dijadikan populasi adalah konsumen yang menggunakan internet Indihome sejumlah 100 orang. Oleh karena itu akan digunakan sampel penelitian karena jumlah pemakai Indihome yang berdomisili di Yogyakarta. Sampel dalam penelitian ini yaitu konsumen yang baru menggunakan layanan internet Indihome. Teknik pengambilan sampel dalam penelitian ini dilakukan dengan teknik purposive sampling. Sedangkan purposive sampling merupakan teknik pengambilan sampel dimana penulis menggunakan pertimbangan sendiri dengan cara sengaja dalam memilih anggota populasi yang dianggap dapat memberikan informasi yang diperlukan oleh penulis Sugiyono (2001) dalam (H. A. Putra, 2017). Usia yang digunakan dalam pengambilan sampel yaitu 1560 tahun, laki-laki perempuan yang bertempat tinggal di Yogyakarta.

\section{Metode Pengumpulan Data}

Metode pengumpulan data dari responden ini dilakukan dengan penelitian menggunakan kuesioner berupa pertanyaan atau pernyataan yang berisikan data dari responden yang diharapkan dapat mengungkap ke sisi iklan, kualitas pelayanan dan kepuasan konsumen terhadap loyalitas konsumen dalam menggunakan layanan internet Indihome yang dibantu program SPSS, excel MSI. tempat dan waktu pengambilan data penelitian ini dilakukan di Yogyakarta waktu penelitian dilaksanakan pada bulan April 2021 untuk uji coba terhadap instrumen penelitian dan membagikan kuesioner bulan Maret 2021 melaksanakan analisis data dan menyusun laporan penelitian. Skala pengukuran dalam penelitian ini menggunakan pengukuran Skala Likert. Skala ini mempunyai kategori-kategori yang mempunyai tingkatan, akan tetapi tiap tingkatan tersebut tidak mempunyai nilai yang absolute atau relatif. Adapun nilai atau ukuran dalam pilihan jawaban atas daftar pertanyaan adalah antara lain:
a. Skor 1 bernilai Sangat Tidak Setuju (STS)
b. Skor 2 bernilai Tidak Setuju (TS)
c. Skor 3 bernilai Netral $(\mathrm{N})$
d. Skor 4 bernilai Setuju (S)
e. Skor 5 bernilai Sangat Setuju (SS)

\section{HASIL DAN PEMBAHASAN}

Uji Validitas

Uji validitas digunakan untuk mengukur sah atau tidak sahnya suatu kuesioner. Uji validitas dilakukan dengan membandingkan nilai $r$ hitung dengan $r$ tabel. Jika $r$ hitung $>r$ tabel, maka item- item pertanyaan dinyatakan valid dan sebaliknya, jika $r$ hitung $<r$ tabel, maka item-item pertanyaan dinyatakan tidak valid. Nilai $r$ hitung dalam uji ini adalah pada kolom Item - total statistics (corrected 
item - total correlation). Sedangkan nilai $\mathrm{r}$ tabel dapat dilihat pada tabel $\mathrm{r}$ dengan persamaan $\mathrm{N}-2=$ $100-2=98$ maka $r$ table $=0,1966$. Beikut adalah hasil Uji Validitas dengan menggunakan IBM SPSS Statistics 25 : (A. Putra, 2017). Hasil pengujian dengan SPSS pada tabel bahwa semua indikator yang digunakan dalam penelitian ini semua variabel memiliki koefisien korelasi yang lebih besar dari r_tabel $(0,195)$ atau $r_{-}$hitung $>$r_tabel, dapat ditarik kesimpulan semua indikator pada semua variabel dinyatakan valid.

Uji Reliabilitas

Menurut Armanto (2018) pengujian reliabilitas atau keandalan instrument menunjukkan sejauh mana suatu pengukuran dapat memberikan hasil yang konsisten bila dilakukan pengukuran kembali dengan gejala yang sama. Uji reliablitas dilakukan terhadap instrumen dengan koefisien Cronbach's Alpha lebih besar dari 0,60 maka instrumen yang digunakan reliabel. Untuk menguji reliablititas dilaksanakan dengan bantuan program SPSS 2.0 (Statistic Package of Social Science) for Windows.

Tabel 1.

\begin{tabular}{llll}
\hline & \multicolumn{2}{l}{ Reliability Statistics } & \\
\cline { 2 - 4 } \multicolumn{1}{c}{ Variabel } & $\begin{array}{l}\text { Cronbach's } \\
\text { Alpha }\end{array}$ & Nilai Kritis & Keterangan \\
\hline Iklan & 0,880 & 0,60 & Realibel \\
\hline Kualitas Pelayanan & 0,861 & 0,60 & Realibel \\
\hline Kepuasan Konsumen & 0,891 & 0,60 & Realibel \\
\hline Loyalitas Konsumen & 0,881 & 0,60 & Realibel \\
\hline
\end{tabular}

Sumber : Data diolah Penulis

Dari tabel diatas dapat disimpulkan bahwa nilai Alpha lebih besar dari 0,60 atau 0,880>0,60, maka hasil uji reliabilitas semua variabel dinyatakan realibel.

\section{Uji Asumsi Klasik}

\section{Uji Multikolinearitas}

Menurut Akila (2017) menjelaskan bahwa uji asumsi klasik jenis ini diterapkan untuk menganalisis regresi berganda yang terdiri atas dua atau tiga variabel bebas/independent variabel. Uji multikolinearitas bertujuan untuk menguji apakah pada model regresi ditemukan kolerasi antar variabel bebas.

Tabel 2.

\begin{tabular}{lll}
\hline \multicolumn{1}{c}{ Variabel Independen } & Tolerance & VIF \\
\hline Iklan $(X 1)$ & 0,344 & 2,911 \\
\hline Kualitas Pelayanan $(X 2)$ & 0,303 & 3,298 \\
\hline Kepuasan Konsumen $(X 3)$ & 0,212 & 4,707 \\
\hline
\end{tabular}

Sumber : Data diolah Penulis

Dapat disimpulkan dari data pada tabel diatas, dapat diketahui bahwa seluruh variabel independen memiliki nilai Tolerance yang besarnya diatas 0,1 dan nilai VIF yang lebih kecil dari 10 . Maka, data yang digunakan dalam penelitian ini bebas dari masalah multikolinieritas.

Uji Heteroskedastisitas

Uji Heteroskedastisitas adalah varian residual yang tidak sama ada semua pengamatan di dalam model regresidimana regresi yang baik seharusnya tidak terjadi heteroskedasitas Priyatno (2010) dalam Sakee (2014). Pengambilan keputusan yaitu dengan cara: a. Jika ada pola tertentu, seperti titik-titik yang ada membentuk suatu pola tertentu yang teratur (begelombang melebar kemudian menyempit), maka terjadi heteroskedastisitas. Jika tidak ada pola yang jelas, seperti titik-titik yang menyebar di atas dan di bawah angka 0 pada sumbu Y, maka tidak terjadi heteroskedastisitas. Dari output regresi titiktitik tidak membentuk pola yang jelas, dan titik-titik menyebar di atas dan di bawah angka 0 pada sumbu Y, jadi dapat disimpulkan bahwa tidak terjadi heteroskedastisitas dalam model regresi 


\section{Gambar 2.}

Scatterplot

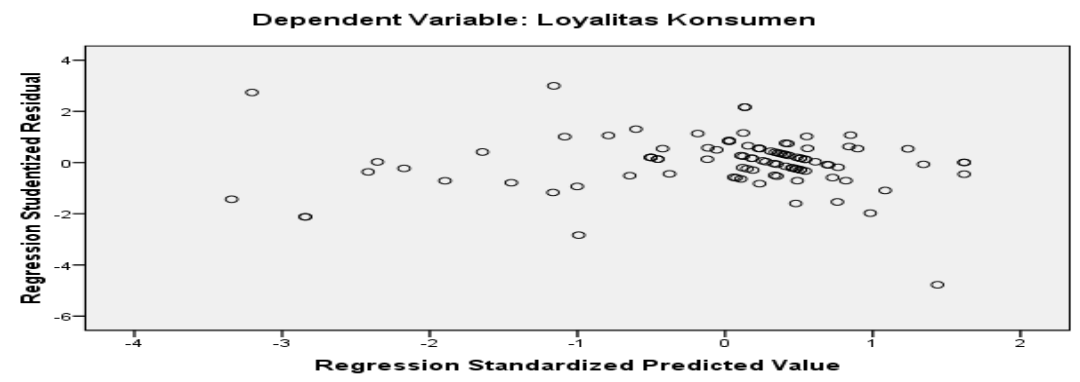

Sumber : Data diolah Penulis

Dari gambar diatas dapat dilihat bahwa penyebaran titik-titik data tidak berpola serta titik-titik menyebar diatas dan dibawah atau disekitar angka 0, maka hal tersebut tidak menandakan terjadi Heteroskedastisitas.

\section{Uji Normalitas}

Uji normalitas menjadi penting dikarenakan dengan normalnya suatu data maka data tersebut dapat dianggap dapat mewakili populasi Priyatno (2010) dalam Sakee (2014).Uji normalitas dapat dilakukan dengan menggunakan grafik maupun menggunakan uji statistik.

Gambar 3.

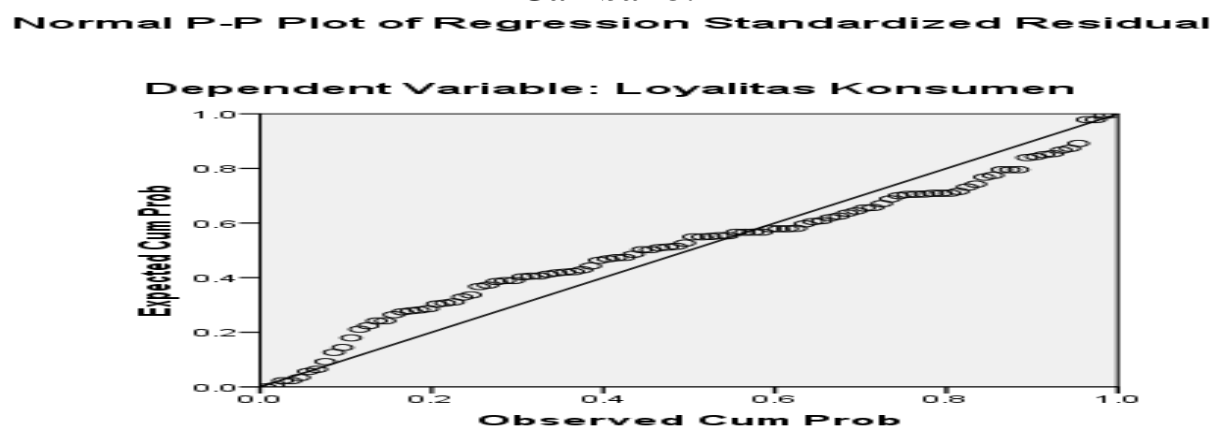

Sumber : Data diolah Penulis

Dari data diatas bahwa uji grafik P-plot dinyatakan terdistribusi dengan normal karena data atau titik-titik itu menyebar disekitar garis diagonal dan mengikuti arah garis diagonal.

\section{Uji Regresi Linear Berganda}

Analisis regresi linier berganda adalah hubungan secara linier antara dua atau lebih variable independen dengan satu variable dependen yang digunakan untuk memprediksi atau meramalkan suatu nilai variable dependen berdasarkan variable independen Priyatno (2010) dalam Sakee (2014).

Tabel 3.

\begin{tabular}{|c|c|c|c|c|c|c|c|c|}
\hline \multicolumn{9}{|c|}{ Coefficients $^{a}$} \\
\hline \multirow[b]{2}{*}{ Model } & & \multicolumn{2}{|c|}{$\begin{array}{l}\text { Unstandardized } \\
\text { Coefficients } \\
\text { Std. }\end{array}$} & \multirow{2}{*}{$\begin{array}{c}\begin{array}{c}\text { Standardized } \\
\text { Coefficients }\end{array} \\
\text { Beta } \\
\end{array}$} & \multirow[b]{2}{*}{$\mathrm{t}$} & \multirow[b]{2}{*}{ Sig. } & \multicolumn{2}{|c|}{ Collinearity Statistics } \\
\hline & & B & $\begin{array}{l}\text { Std. } \\
\text { Error }\end{array}$ & & & & Tolerance & VIF \\
\hline \multirow{4}{*}{1} & (Constant) & $-2,168$ & 2,103 & & $-1,031$ & ,305 & & \\
\hline & Iklan &, 144 &, 080 & , 185 & 1,809 & ,074 & ,344 & 2,911 \\
\hline & $\begin{array}{l}\text { Kualitas } \\
\text { Pelayanan }\end{array}$ & ,241 & ,100 & ,262 & 2,413 & ,018 & ,303 & 3,298 \\
\hline & $\begin{array}{l}\text { Kepuasan } \\
\text { Konsumen }\end{array}$ & ,306 & ,095 & ,420 & 3,237 &, 002 & ,212 & 4,707 \\
\hline
\end{tabular}

a. Dependent Variable: Loyalitas Konsumen 
Dari hasil tabel diatas dilihat nilai Beta dari nilai iklan $(X 1)=0,185$, nilai kualitas pelayanan $(X 2)=0,262$ dan nilai kepuasan konsumen $=0,420$. Oleh karena itu, persamaan regresi linear berganda, yaitu: $\mathrm{Y}=0,185 \mathrm{X} 1+0,262 \mathrm{X} 2+0,420 \mathrm{X} 3$

Analisis Koefisien Determinasi (R2)

Koefisien determinasi digunakan untuk mengetahui seberapa jauh pengaruh variabel X (iklan, kualitas pelayanan, dan kepuasan konsumen) terhadap variabel Y (loyalitas konsumen).

Tabel 4.

\begin{tabular}{lcccc}
\hline \multicolumn{5}{c}{ Model Summary $^{\mathbf{b}}$} \\
\hline Model & $\mathrm{R}$ & $\begin{array}{c}\mathrm{R} \\
\text { Square }\end{array}$ & $\begin{array}{c}\text { Adjusted } \mathrm{R} \\
\text { Square }\end{array}$ & $\begin{array}{c}\text { Std. Error of the } \\
\text { Estimate }\end{array}$ \\
\hline 1 &, $810^{\mathrm{a}}$ &, 656 &, 646 & 2,227 \\
\hline a. Predictors: (Constant), Kepuasan Konsumen, Iklan, Kualitas Pelayanan \\
\hline \multicolumn{2}{l}{ b. Dependent Variable: Loyalitas Konsumen } \\
\hline
\end{tabular}

Sumber : Diolah Penulis

Dari tabel output SPSS diatas, didapatkan nilai Adjusted R Square (koefisien determinasi) sebesar 0,646 yang artinya pengaruh variabel independen $(\mathrm{X})$ terhadap variabel dependen $(\mathrm{Y})$ hanya mampu menjelaskan kepengaruhannya sebesar $64,6 \%$ sisanya sebesar 35,4\% dijelaskan oleh variabel yang tidak diteliti dalam model penelitian ini.

\section{Pengujian Hipotesis}

Uji t (Uji koefisien regresi secara parsial)

Dengan membandingkan nilai t hitungnya dengan $t$ tabel Apabila $t$ tabel $>t$ hitung, maka Ho diterima dan $\mathrm{H} 1$ ditolak. Apabila $\mathrm{t}$ tabel $<\mathrm{t}$ hitung maka Ho ditolak dan H1 diterima Dengan tingkat signifikansi 95\% $(\alpha=5 \%)$. Dengan menggunakan angka probabilitas signifikansi. Apabila angka probabilitas signifikansi > 0,05 maka Ho diterima dan H1 ditolak. Apabila angka probabilitas signifikansi $<0,05$ maka Ho ditolak dan $\mathrm{H} 1$ diterima.

Tabel 5.

\begin{tabular}{|c|c|c|c|c|c|c|c|c|}
\hline \multicolumn{9}{|c|}{ Coefficients $^{a}$} \\
\hline \multirow{2}{*}{\multicolumn{2}{|c|}{ Model }} & \multirow{2}{*}{$\begin{array}{c}\begin{array}{c}\text { Unstandardized } \\
\text { Coefficients }\end{array} \\
\text { B }\end{array}$} & \multicolumn{2}{|c|}{$\begin{array}{c}\text { Standardized } \\
\text { Coefficients }\end{array}$} & \multirow[t]{2}{*}{$\mathrm{t}$} & \multirow[t]{2}{*}{ Sig. } & \multicolumn{2}{|c|}{$\begin{array}{l}\text { Collinearity } \\
\text { Statistics }\end{array}$} \\
\hline & & & $\begin{array}{l}\text { Std. } \\
\text { Error }\end{array}$ & Beta & & & Tolerance & VIF \\
\hline 1 & (Constant) & $-2,168$ & 2,103 & & $-1,031$ & ,305 & & \\
\hline & Iklan &, 144 & ,080 & , 185 & 1,809 & 074 & ,344 & ,2911 \\
\hline & $\begin{array}{l}\text { Kualitas } \\
\text { Pelayanan }\end{array}$ & ,241 & 100 & ,262 & 2,413 & 0,18 & ,303 & 3,298 \\
\hline & $\begin{array}{l}\text { Kepuasan } \\
\text { Konsumen }\end{array}$ & ,306 & 95 & , 420 & 3,237 & 0,02 & ,212 & 4,707 \\
\hline
\end{tabular}

a. Dependent Variable: Loyalitas

Konsumen

Sumber : Data diolah Penulis

\section{PEMBAHASAN}

Berdasarkan hasil analisis deskriptif dan uji hipotesis dari hasil analisis, maka dijelaskan dalam pembahasan berikut ini:

Pengaruh Iklan terhadap loyalitas konsumen dalam menggunakan layanan internet Indihome

Menurut Putra (2017) istilah periklanan merujuk kepada pemahaman keseluruhan proses yang meliputi persiapan, perencanaan, pelaksanaan, dan pengawasan penyampaian pesan. Berdasarkan hasil uji diatas menunjukkan bahwa penilaian terendah jawaban pada variabel Iklan terjadi pada pernyataan bahwa persiapan, perencanaan, pelaksanaan, dan pengawasan penyampaian pesan pengucapan kalimat 
iklan dalam slogan Indihome mudah dihafalkan. Sehingga dengan adanya pernyataan ini membuktikan bahwa dampak dari Indihome ternyata konsumen merasa pengucapan iklan tidak mudah di hafalkan.

\section{Pengaruh Kualitas Pelayanan terhadap loyalitas konsumen dalam menggunakan layanan internet Indihome}

Penelitian yang dilakukan oleh Wiyadi (2016) Variabel kualitas pelayanan memiliki pengaruh secara positif dan signifikan terhadap loyalitas pelanggan. Artinya semakin tinggi kualitas pelayanan sebuah perusahaan maka semakin tinggi loyalitas pelanggan atau semakin rendah kualitas pelayanan sebuah perusahaan maka semakin rendah loyalitas pelanggan. Berdasarkan hasil uji diatas menunjukkan bahwa penilaian terendah jawaban pada variabel Kualitas Pelayanan terjadi pada pernyataan bahwa petugas Indihome cepat tanggap pada keluhan dari konsumen. Sehingga dengan adanya pernyataan ini membuktikan bahwa dampak dari Indihome ternyata konsumen merasa petugas Indihome tidak cepat tanggap pada keluhan dari konsumen.

\section{Pengaruh Kepuasan Konsumen terhadap loyalitas konsumen dalam menggunakan layanan internet Indihome}

Penelitian yang dilakukan oleh Wiyadi (2016) variabel kepuasan pelanggan memiliki pengaruh yang signifikan terhadap loyalitas pelanggan. Artinya semakin tinggi kepuasan pelanggan maka semakin tinggi pula loyalitas pelanggan atau semakin rendah kepuasan pelanggan maka semakin rendah pula loyalitas pelanggan. Pada penelitian ini menunjukan hubungan kepuasan konsumen berpengaruh positif signifikan terhadap loyalitas konsumen dalam menggunakan layanan internet Indihome dapat dilihat dari nilai Sig sebesar 0,02 lebih kecil dari nilai $<0,05$ yang berarti bahwa semakin tinggi kepuasan konsumen seseorang terhadap produk Indihome maka semakin besar juga kemungkinan membeli lagi dan setia pada produk tersebut.

\section{KESIMPULAN}

Berkembangnya teknologi jaringan internet Indonesia Digital Home (Indihome) yang merupakan salah satu layanan yang berupa paket layanan komunikasi dan data. Penilaian pelanggan Setelah menggunakan produk indihome, pelanggan yang puas tentunya akan memberikan ulasan positif sekaligus merekomendasikannya kepada orang lain. Sementara itu, konsumen yang merasa tidak puas tentunya akan kecewa dan memberikan keluhan. Dengan pelayanan yang berkualitas maka konsumen akan tetap berkeinginan untuk menggunakan produk Indihome karena mereka merasa puas terhadap pelayanan yang di berikan sehingga mereka menjadi loyal. Hasil ini menjelaskan bahwa pada umumnya konsumen akan memperhitungkan faktor iklan, Kualitas Pelayanan, Kepuasan konsumen yang dapat diperoleh dari uang yang akan dikeluarkannya dan peningkatan kualitas pelayanan akan meningkatkan loyalitas konsumen.

\section{SARAN}

1. Saran praktis yang dimunculkan pada penelitian yang sudah diperoleh bahwa hasil deskrpitif menunjukan iklan dan kualitas pelayanan terhadap loyalitas konsumen dalam menggunakan layanan Internet Indihome yang menunjukan hasil yang tidak signifikan maka perlu menambahkan iklan dan kualitas pelayanan terhadap loyalitas konsumen dalam menggunakan layanan Internet Indihome untuk meningkatkan intensitas dalam mengomunikasikan layanan Internet Indihome agar tepat sasaran dengan menyasar konsumen yang loyal pada layanan Internet Indihome. Pada penelitian ini diketahui bahwa loyalitas konsumen dalam menggunakan layanan Internet Indihome maka dari itu peneliti menyarankan agar terus mempertahankan dan meningkatkan kualitas produk dan berinovasi mengikuti perkembangan segmen pemasaran tetapi tetap mengutamakan nilai-nilai yang berwawasan positif terhadap layanan Internet Indihome

2. Saran teoritis

Disarankan bagi peneliti lain agar dapat melakukan penelitian lebih mendalam terhadap kontribusi dari iklan, kualitas pelayanan dan kepuasan konsumen determinan mengenai loyalitas konsumen dalam menggunakan layanan Internet Indihome dan dapat melakukan penelitian dengan melihat korelasi antara iklan dan kualitas pelayanan determinan mengenai loyalitas konsumen dalam menggunakan layanan Internet Indihome. 


\section{REFERENSI}

Akila. (2017). Pengaruh Insentif Dan Pengawasan Terhadap Produktivitas Kerja Karyawan Pada Cv. Vassel Palembang Oleh. Ecoment Global, 2, 35-48.

Armanto, I. D. (2018). Fakultas Ekonomi dan Bisnis Universitas Udayana , Bali , Indonesia Perkembangan teknologi komunikasi di Indonesia saat ini semakin canggih dalam kehidupan masyarakat yang menggunakan dan tidak dapat dihindarkan. Bertambahnya banyaknya masyarakat yang men. Manajemen Unud, 7(3), 1282-1309.

Asta, I. N., \& Jaya, G. (2019). Kualitas Layanan Terhadap Loyalitas Pelanggan Fakultas Ekonomi dan Bisnis Universitas Udayana ( Unud), Bali, Indonesia Perkembangan industri otomotif di Indonesia sangat cepat dan cenderung meningkat tiap tahunnya, seiring dengan kebutuhan dan perminta. 8(1), 7458-7485.

Aulawi, H., Siliwangi, J., Rawa, N., Bekasi, P., \& Indonesia, T. (2016). Kepuasan Konsumen , Biaya Berpindah , Persepsi Harga, dan Citra Perusahaan Terhadap Loyalitas Konsumen Pada Penyedia Jasa Internet Telkom Speedy. 4(1), 93-116.

Jihan Nafisa, I. M. S. (2018). Analisis Pengaruh Kualitas Layanan, Harapan Kinerja Dan Citra Perusahaan Terhadap Loyalitas Pelanggan Melalui Kepuasan Pelanggan Sebagai Variabel Intervening (Studi Pada Rumah Sakit Islam Sultan Agung Semarang). Diponegoro Journal Of Management, 7(3), 1-26.

Noor, M. (2018). Pengaruh Iklan, Citra Merek Dan Kepuasan Konsumen Terhadap Loyalitas Konsumen Produk "Rexona” Di Banjarmasin. Ilmu Manajemen Indonesia, 1(2), 167-177.

Paramananda, N., \& Satria, K. A. (2015). Pengaruh tarif premi, kualitas pelayanan, daya tarik iklan, dan citra merek terhadap loyalitas nasabah. E-Jurnal Manajemen Unud, 4(4), 1134-1148.

Putra, A. (2017). Pengaruh Iklan Dan Kepercayaan Merek Terhadap Minat Beli Konsumen (Studi Pada Texas Chicken Pekanbaru) Oleh. JOM FISIP, 4(1), 1-11.

Putra, H. A. (2017). Pengaruh Kualitas Pelayanan Terhadap Loyalitas Konsumen Melalui Kepuasan Konsumen Sebagai Variabel Intervening (Studi Kasus Pada Konsumen Pt. Lontar Media Digital Printing Semarang). Diponegoro Journal Of Social And Political, 1-8.

Sakee, U. (2014). Corporate Financial Performance Effects Of Macro Economic Factors Against Stock Return. Tetrahedron Letters, 55(2), 3909.

Sukawati2, I. M. A. J. T. G. R. (2018). Pengaruh Persepsi Harga, Promosi, Dan Kualitas Pelayanan Terhadap Kepuasan Dan Dampaknya Terhadap Loyalitas Konsumen. E-Jurnal Manajemen Unud, 7(11), 5955-5982.

Utama1, I. D. A. G. A., \& Kusuma2, A. A. G. A. A. (2019). Peran Kepuasan Pelanggan Dalam Memediasi Pengaruh Kualitas Pelayanan Terhadap Loyalitas Pelanggan. Manajemen, 8(11), $6468-6487$.

Wahyono. (2018). Pengaruh Kualitas Pelayanan,Citra Merek,Dan Kualitas Produk Terhadap Loyalitas Konsumen Melalui Kepuasan Konsumen. Management Analysis, 7(1), 111-119.

Winarti, C. E. (2016). Pengaruh kualitas layanan, iklan, dan citra merek terhadap loyalitas nasabah bank bukopin di daerah setiabudi, jakarta selatan. ProBank, Jurnal Ekonomi Dan Perbankan, 2(2), 918.

Wiyadi, E. S. dan. (2016). Pengaruh kualitas pelayanan, harga, dan citra merek terhadap loyalitas pelanggan dengan kepuasan pelanggan sebagai variabel pemediasi. Jurnal Ekonomi Manajemen Sumber Daya, 18(2), 102-112. 